\title{
Pengembangan Multimedia Interaktif Video Senam Animasi Berbasis Budaya Khas Kalimantan Barat
}

\author{
Desni Yuniarni ${ }^{\varpi_{1}}$, Reni Puspita Sari ${ }^{2}$, Ahmad Atiq ${ }^{3}$ \\ Pendidikan Guru Pendidikan Anak Usia Dini, Universitas Tanjungpura ${ }^{1}$ \\ Sistem Informasi, Universitas Tanjungpura ${ }^{2}$ \\ Pendidikan Kesehatan, Jasmani dan Rekreasi, Universitas Tanjungpura ${ }^{3}$ \\ DOI: $10.31004 /$ obsesi.v4i1.331
}

\begin{abstract}
Abstrak
Penelitian ini bertujuan mengembangkan multimedia interaktif berbentuk video senam animasi berbasis budaya khas Kalimantan Barat dalam pembelajaran di PAUD. Model pengembangan dalam penelitian ini mengacu pada model penelitian dan pengembangan $4 \mathrm{D}$ (four-D) yaitu define, design, develop, dan disseminate dapat diadaptasikan menjadi 4P yaitu pendefinisian, perancangan, pengembangan, dan penyebaran. Subjek dalam penelitian ini guru-guru di PAUD Anggrek Kabupaten Kubu Raya. Dilakukan uji coba produk kepada para anak PAUD usia 4-5 tahun dan usia 5-6 tahun di PAUD Anggrek yang berjumlah 40 orang anak. Sumber data dalam penelitian ini juga melibatkan dosen-dosen prodi PG-PAUD FKIP UNTAN, Psikolog Perkembangan Anak untuk mendapatkan data validasi ahli media dan ahli materi. Alat pengumpulan data yang digunakan adalah wawancara, observasi dan angket. Teknik analisis data yang digunakan dalam penelitian ini teknik analisis kualitatif dan analisis kuantitatif. Hasil dari penelitian ini adalah perancangan multimedia interaktif berbentuk video senam animasi berbasis budaya khas Kalimantan Barat, dinilai sangat layak untuk digunakan dan dapat menarik minat anak untuk melakukan gerakan senam.

Kata Kunci: senam berbasis budaya khas kalimantan barat; multimedia interaktif; anak usia dini
\end{abstract}

\begin{abstract}
The purpose of this research is to develop interactive multimedia in the form of video animation based on culture of West Kalimantan in learning in PAUD. The development model in this study refers to the 4D (four-D) research and development model that is define, design, develop, and disseminate can be adapted into $4 \mathrm{P}$, namely defining, designing, developing, and spreading. The subjects in this study were the teachers in PAUD Anggrek, Kubu Raya Regency. The product was tested on PAUD children aged 4-5 years and 5-6 years old at PAUD Anggrek, which numbered 40 children. The data source in this study also involved lecturers from the PG-PAUD FKIP UNTAN, Child Development Psychologists to obtain validation data from media experts and material experts. Data collection tools used were interviews, observation and questionnaires. Data analysis techniques used in this study are qualitative analysis techniques and quantitative analysis. The results of this study are the design of interactive multimedia in the form of video animation based on culture of West Kalimantan, considered to be very feasible to use and can attract the interest of children to do gymnastics movements.
\end{abstract}

Keywords: West Kalimantan culture-based gymnastics, interactive multimedia

Copyright (c) 2019 Khairunisa Kusumaningrum, Sugeng Bayu Wahyono

$\triangle$ Corresponding author:

Email Address : desni.yuniarni@fkip.untan.ac.id (Jalan Prof. Dr. Hadari Nawawi, Pontianak)

Received 11 November 2019, Accepted 28 November 2019, Published 28 November 2019

280 | Jurnal Obsesi : Jurnal Pendidikan Anak Usia Dini, 4(1), 2020 


\section{PENDAHULUAN}

Salah satu aspek perkembangan yang perlu distimulasi untuk anak dalam pembelajaran di pendidikan anak usia dini (PAUD) adalah aspek perkembangan motorik. Menurut Yuliansih (2015), yang dimaksud dengan perkembangan motorik yang dipengaruhi oleh unsur kematangan dan pengendalian gerak tubuh. Sedangkan motorik adalah gerakan yang dilakukan oleh seluruh. Dengan demikian perkembangan motorik adalah perkembangan yang dipengaruhi oleh adanya unsur kematangan dan pengendalian gerak yang dilakukan oleh seluruh tubuh.

Perkembangan motorik terbagi atas perkembangan motorik halus dan motorik kasar. Sumantri (2005:143), menyatakan bahwa motorik halus adalah pengorganisasian penggunaan sekelompok otot-otot kecil seperti jari-jemari dan tangan yang sering membutuhkan kecermatan dan koordinasi dengan tangan, keterampilan yang mencakup pemanfaatan menggunakan alat-alat untuk mengerjakan suatu objek. Sedangkan motorik kasar menurut Samsudin (2008), gerakan motorik kasar merupakan bagian dari aktivitas yang mencakup keterampilan otot-otot besar, gerakan ini lebih menuntut kekuatan fisik dan keseimbangan. Oleh karena itu dapat disimpulkan bahwa perbedaan antara motorik halus dan motorik kasar adalah pada motorik halus digerakkan oleh otot-otok kecil seperti gerakan jari-jemari dan tangan yang membutuhkan kecermatan dan ketelitian, sedangkan motorik kasar adalah gerakan yang melibatkan otot-otot besar yang membutuhkan kekuatan fisik dan keseimbangan tubuh.

Manfaat stimulasi motorik kasar bagi anak usia dini yakni untuk meningkatkan kemampuan mengelola, mengontrol gerakan tubuh dan koordinasi, serta meningkatkan keterampilan tubuh dan cara hidup sehat sehingga dapat menunjang pertumbuhan jasmani yang kuat, sehat dan terampil (Sujiono, 2010). Selain itu juga, Sujiono (2011:), mengungkapkan jika anak banyak bergerak maka akan semakin banyak manfaat yang dapat diperoleh anak ketika ia makin terampil menguasai gerakan motoriknya.

Stimulasi perkembangan motorik halus dan motorik kasar anak diusahakan dikemas dalam bentuk permainan/perlombaan agar anak merasa tertarik dan mendapatkan kesenangan. (Zulkifli, 2002). Gerakan senam adalah adalah salah satu bentuk stimulasi motorik kasar yang dikemas dalam bentuk yang menarik karena diriingi lagu yang membuat anak bersemangat untuk bergerak. Hal ini sependapat dengan Gallahue dalam Samsudin bahwa untuk mengembangkan pola-pola gerak anak sebaiknya dilakukan melalui aktivitas-aktivitas seperti menari, permainan, olahraga dan senam (Farihatun: 2016). Oleh karena itu, senam dapat dijadikan sarana untuk meningkatkan kemampuan motorik kasar anak, dapat mendukung perkembangan jasmani anak melalui kekuatan fisik dan otot anak.

Gerakan senam yang diberikan kepada anak merupakan bagian dari pendidikan jasmani untuk anak. Melalui pendidikan jasmani yang diarahkan dengan baik, anak-anak akan mengembangkan keterampilan yang berguna bagi pengisian waktu senggang, terlibat dalam aktivitas yang kondusif untuk mengembangkan hidup sehat, berkembang secara sosial, dan menyumbang pada kesehatan fisik dan mentalnya (Husdarta, 2009). Pendidikan jasmani untuk anak tidak hanya bermanfaat untuk kesehatan fisik anak, namun juga dapat berfungsi sebagai sarana pembinaan bakat olahraga pada anak. Melalui pembinaan sejak dini yang benar dan berkesinambungan akan memperluas kemungkinan memperoleh olahragawan di masa mendatang (Apta, 2014). Pembinaan dalam pendidikan jasmani merupakan deteksi dini bakat anak dalam bidang olahraga.

Berbagai manfaat lain yang diperoleh anak dengan melakukan gerakan senam diantaranya, adalah anak akan memiliki daya tahan terhadap penyakit, daya tahan terhadap kelelahan, laju pertumbuhan dan perkembangan, bahkan tingkat intelektual akan lebih baik dibanding dengan anak yang tidak aktif (Paiman, 2009). Senam merupakan salah satu kegiatan yang dapat merangsang perkembangan fisik motorik anak usia dini. Senam dengan diiringi musik dan lagu menjadikan kecerdasan musik anak pun turut terbina (Erick, 2014). 
Senam dapat membantu perkembangan kemampuan gerak lokomotor seperti berjalan, berlari, meloncat, melompat, skipping, berlari cepat, dan berjalan, sedangkan kemampuan gerak nonlokomotor seperti keseimbangan, memutarkan badan, berbalik arah, dan melipat badan. Kegiatan tersebut membantu anak-anak untuk dasar-dasar kecerdasan otak, keseimbangan, dan koordinasi (Galih dan Pamuji, 2013). Menurut Syahara, aktivitas senam adalah suatu proses pembentukan gerak dasar. Anak akan selalu merasa penasaran bagaimana mereka dapat mengetahui dirinya melalui gerakan (dalam Nisnayeni, 2012)

Berdasarkan pendapat para ahli tersebut, dapat disimpulkan bahwa senam memberikan banyak manfaat bagi perkembangan anak usia dini.

Namun, kenyataan yang ada menunjukkan bahwa tidak semua anak senang melakukan gerakan senam dalam pembelajaran di PAUD, terutama anak-anak di PAUD Anggrek Kabupaten Kubu Raya. Olahraga senam yang dilakukan anak biasanya diiringi oleh lagu sambil mencontoh gerakan yang dilakukan oleh guru. Jenis lagu dan gerakan senam yang diberikan kepada anak terbatas pada lagu dan gerakan senam yang diketahui oleh guru, sehingga cenderung kurang bervariasi. Anak hanya melakukan gerakan senam dan iringan lagu yang sama terus-menerus secara berulang kali setiap, sehingga anak menjadi kurang tertarik dan tidak bersemangat apabila diajak melakukan olahraga senam bersama di halaman.

Oleh karena itu, agar anak memiliki minat dalam melakukan gerakan senam di PAUD, dirancang sebuah video animasi 2 dimensi dengan motion graphic dengan iringan lagu khas Kalimantan Barat Olahraga yang kurang diminati oleh anak adalah olahraga senam. Olahraga senam yang dilakukan anak biasanya diiringi oleh lagu sambil mencontoh gerakan yang dilakukan oleh guru. Jenis lagu dan gerakan senam yang diberikan kepada anak terbatas pada lagu dan gerakan senam yang diketahui oleh guru, sehingga cenderung kurang bervariasi. Anak hanya melakukan gerakan senam dan iringan lagu yang sama terus-menerus secara berulang kali setiap, sehingga anak menjadi kurang tertarik dan tidak bersemangat apabila diajak melakukan olahraga senam bersama di halaman.

Menurut Piaget (Ibda, 2015), anak usia dini berada pada rentang usia 2-7 tahun dimana pada usia ini, tahapan perkembangan kognitifnya berada pada tahapan praoperasional. Pada tahap ini anak membangun pengetahuannya dengan cara merasakan, melakukan dan terlibat langsung dalam aktivitas pembelajarannya. Anak pada usia ini akan memahami pembelajaran yang diberikan apabila menggunakan media yang kongkrit, sehingga mereka dapat melakukan, merasa, meraba dan bereksplorasi terhadap media yang diberikan.

Diharapkan dengan adanya perancangan video senam animasi 2 dimensi dengan motion grapic, anak dapat tertarik melakukan gerakan senam, karena menggunakan media yang kongkrit yang bisa mereka lihat dan dapat ditiru gerakan senamnya. Selain itu juga, video senam tersebut dibuat dengan iringan lagu khas Kalimantan Barat, sehingga dapat juga mengenalkan lagu khas daerah Kalimantan Barat kepada anak dalam pembelajaran di PAUD.

Suyanto (2003) yang menjelaskan multimedia adalah pemanfaatan komputer untuk membuat dan menggabungkan teks, grafik, audio, gambar bergerak (video dan animasi) dengan menggabungkan link dan tool yang memungkinkan pemakai melakukan navigasi, berinteraksi, berkreasi, dan berkomunikasi. Menurut Vaughan (2011), terdapat tiga jenis multimedia, yaitu multimedia interaktif, multimedia hiperaktif, multimedia linear, dan multimedia. Dapat disimpulkan bahwa multimedia interaktif adalah pemanfaatan komputer dalam pembuatan teks, grafik, audio dan gambar bergerak yang memungkinkan pemakainya untuk berinteraksi dan berkomunikasi.

Dengan dikembangkannya media pembelajaran berbentuk multimedia interaktif ini, diharapkan dapat meningkatkan minat anak-anak di PAUD Anggrek untuk melakukakan senam yang sangat bermanfaat bagi kesehatan tubuhnya, perkembangan motoriknya dan aspek perkembangan lainnya. 

DOI: $10.31004 /$ obsesi.v4i1.331

\section{METODOLOGI}

Model pengembangan dalam penelitian ini mengacu pada model penelitian dan pengembangan 4D (four-D). Menurut Triyanto (2010: 189), model pengembangan 4D yaitu define, design, develop, dan disseminate dapat diadaptasikan menjadi 4P yaitu pendefinisian, perancangan, pengembangan, dan penyebaran.

Tabel 1. Alur Pengembangan Penelitian

\begin{tabular}{|c|c|c|}
\hline TAHAP & KEGIATAN & DETAIL \\
\hline I & Pendefinisian & $\begin{array}{l}\text { a. Menentukan tujuan } \\
\text { b. Menentukan tema dalam kurikulum PAUD } \\
\text { c. Menentukan materi } \\
\text { d. Menentukan jenis media pembelajaran } \\
\text { e. Membuat story board }\end{array}$ \\
\hline II & Perancangan & $\begin{array}{l}\text { Menentukan alur, tokoh, dan latar } \\
\text { Membuat skenario } \\
\text { Penyiapan materi } \\
\text { Perancangan tulisan, gambar dan suara }\end{array}$ \\
\hline III & Pengembangan & $\begin{array}{l}\text { Validasi ahli materi yaitu guru PAUD Anggrek, dosen PG-PAUD } \\
\text { FKIP UNTAN, Psikolog Perkembangan Anak } \\
\text { Validasi ahli media yaitu dosen PG-PAUD yang ahli dalam media } \\
\text { pembelajaran untuk PAUD } \\
\text { Uji coba produk (video senam animasi } 2 \text { dimensi dengan motion } \\
\text { graphic) ke anak-anak di PAUD Anggrek } \\
\text { Revisi }\end{array}$ \\
\hline IV & Penyebaran & $\begin{array}{l}\text { Jurnal nasional terakreditasi } \\
\text { Upload ke Youtube } \\
\text { Memperoleh HAKI }\end{array}$ \\
\hline
\end{tabular}

Subjek (sumber data primer) dalam penelitian ini adalah guru-guru di PAUD Anggrek Kabupaten Kubu Raya. Selain para guru-guru tersebut, dilakukan uji coba produk kepada para anak PAUD usia 4-5 tahun dan usia 5-6 tahun di PAUD Anggrek yang berjumlah 40 orang anak.

Sumber data dalam penelitian ini juga melibatkan dosen-dosen prodi PG-PAUD FKIP UNTAN, Psikolog Perkembangan Anak untuk mendapatkan data validasi ahli media dan ahli materi.

Metode pengumpulan data merupakan langkah utama dalam penelitian, dengan maksud untuk mendapatkan data yang akurat dan dapat dipertanggung jawabkan. Menurut Sugiyono (2012) mengatakan ada empat macam metode pengumpulan data; yaitu observasi, wawancara, dokumentasi, dan gabungan/triangulasi.

Mengacu pada Sugiyono, penelitian ini menggunakan metode pengumpul data berupa wawancara. Metode ini digunakan ketika peneliti melakukan ujicoba produk untuk melihat dan mengetahui keefektifan media yang dikembangkan untuk mendapatkan data mengenai kelebihan dan kelemahan produk yang dari data tersebut akan dilakukan revisi atau perbaikan produk.

Selain itu juga, penelitian ini menggunakan angket/kuesioner. Metode ini digunakan peneliti untuk mendapatkan data berupa uji validitas atau kelayakan multimedia interaktif dalam bentuk gerakan senam animasi berbasis budaya Khas Kalimantan Barat dari segi materi maupun segi kelayakan media yang digunakan untuk anak usia dini dan dapat mencapai tujuan dari pengembangan produk.

Teknik analisis data yang digunakan dalam penelitian ini adalah teknik analisis deskriptif yang dilakukan dengan menggunakan statistik deskriptif. Teknik analisis data yang digunakan dalam penelitian ini adalah teknik analisis kualitatif dan analisis kuantitatif.

Analisis kualitatif digunakan untuk mendeskripsikan hasil observasi, wawancara, saran dosen, validasi, dan catatan dokumentasi saat diimplementasikan. Data tersebut 
dianalisis secara deskriptif kualitatif, beberapa saran akan digunakan untuk perbaikan produk pada tahap revisi sedangkan catatan dokumentasi dideskripsikan untuk menggetahui efektifitas produk yang dikembangkan saat digunakan dalam pembelajaran dimana dalam penelitian ini terkait dengan respon saat menggunakan multimedia interaktif tersebut.

Analisis kuantitatif digunakan untuk mendeskripsikan kualitas media berdasarkan penilaian guru PAUD. Teknik kualitatif dilakukan dengan pemberian kriteria yang diadopsi dari Azwar (2007).

Penelitian ini akan melakukan dua tahap analisis yaitu menentukan nilai rata-rata yang di peroleh dan membuat kriteria menjadi 4 kriteria, yaitu, sangat layak, layak, kurang layak, dan tidak layak. Dengan rumus sebagai berikut:

Nilai rata-rata perolehan:

$$
\begin{aligned}
& \overline{\mathrm{X}}=\frac{1}{\text { banyak validator }} \times \frac{\sum x}{n} \\
& \text { Keterangan: } \\
& \overline{\mathrm{x}}=\text { rata }- \text { rata perolehan skor } \\
& \sum \mathrm{x}=\text { jumlah skor yang diperoleh } \\
& n \quad=\text { banyaknya butir pernyataan }
\end{aligned}
$$

Tabel 2. Pengkategorisasian/kriterium:

\begin{tabular}{|c|c|c|}
\hline No. & Rentang Skor & Kriteria \\
\hline 1 & $\mathrm{X}>\mathrm{Mi}+1,5 \mathrm{Sbi}$ & Sangat Layak \\
\hline 2 & $0<\mathrm{X} \leq \mathrm{Mi}+1,5 \mathrm{Sbi}$ & Layak \\
\hline 3 & $M i-1,5 \mathrm{Sbi}<\mathrm{X} \leq 0$ & Kurang Layak \\
\hline 4 & $\mathrm{X} \leq \mathrm{Mi}-1,5 \mathrm{Sbi}$ & Tidak Layak \\
\hline
\end{tabular}

Keterangan :

Mi $($ mean ideal $)=1 / 2 x($ skor maksimal ideal + skor minimal ideal $)$

Sbi $($ simpangan baku ideal $)=1 / 6 x$ (skor maksimal ideal - skor minimal ideal $)$

\section{HASIL DAN PEMBAHASAN}

Hasil dari penelitian ini terbagi pada beberapa tahap, yaitu tahap pendefinisian, tahap ini terdiri dari beberapa bagian, yaitu, menentukan tujuan. Tujuan dirancangnya multimedia interaktif berbentuk video senam animasi berbasis budaya khas Kalimantan Barat dalam pembelajaran di PAUD adalah untuk meningkatkan minat anak dalam melakukan olahraga senam di PAUD. Minat anak dalam melakukan senam perlu ditingkatkan, seperti yang dikemukakan oleh Paiman (2009), yang mengatakan bahwa senam memberikan banyak manfaat kepada anak diantaranya yaitu anak akan memiliki daya tahan terhadap penyakit, daya tahan terhadap kelelahan, laju pertumbuhan dan perkembangan, bahkan tingkat intelektual akan lebih baik dibanding dengan anak yang tidak aktif. Oleh karena itu penelitian ini bertujuan untuk merancang multimedia pembelajaran berbentuk senam animasi sehingga dapat bermanfaat untuk anak usia dini.

Tahap selanjutnya adalah menentukan tema dalam kurikulum PAUD. Tema yang sesuai dalam pengembangan multimedia ini adalah diriku. Tema ini memiliki sub tema tubuhku, dimana cakupan temanya diantaranya mengenal anggota tubuh, bagian-bagian anggota tubuh, fungsi dan gerak anggota tubuh. Berdasarkan kurikulum PAUD 2013, maka tema yang sesuai dalam pengembangan multimedia ini adalah diriku. Tema ini memiliki sub tema tubuhku, dimana cakupan temanya diantaranya mengenal anggota tubuh, bagianbagian anggota tubuh, fungsi dan gerak anggota tubuh. 

DOI: $10.31004 /$ obsesi.v4i1.331

Tema ini sesuai dengan materi yang terdapat dalam multimedia dimana, dalam multimedia tersebut, anak dikenalkan dengan bagian-bagian anggota tubuhnya, fungsi anggota tubuhnya, bagaimana cara membersihkan anggota tubuhnya, bagian tubuh yang tidak boleh disentuh oleh orang lain dan apa yang harus dilakukan jika ada orang lain menyentuh bagian tubuh tersebut.

Tahap lainnya adalah menentukan materi. Materi yang terdapat dalam multimedia interaktif ini adalah gerakan senam untuk anak usia dini. Materi yang terdapat dalam multimedia interaktif ini adalah gerakan senam untuk anak usia dini, diantaranya adalah

\section{Gerakan senam yang diiringi lagu Sungai Kapuas:}

\section{Gerakan ke-1}

Gerakan ke samping dengan 1 step tungkai dan 1 step tangan mengayunkan dari arah depan ke belakang dari gerakan menutup lengan dan membuka lengan/down swif dan up swif. Gerakan ini menggunakan tangan dan kaki secara bersamaan atau secara terkoordinasi Manfaat dari gerakan ini adalah untuk melatih kelenturan, keseimbangan dan kelincahan.
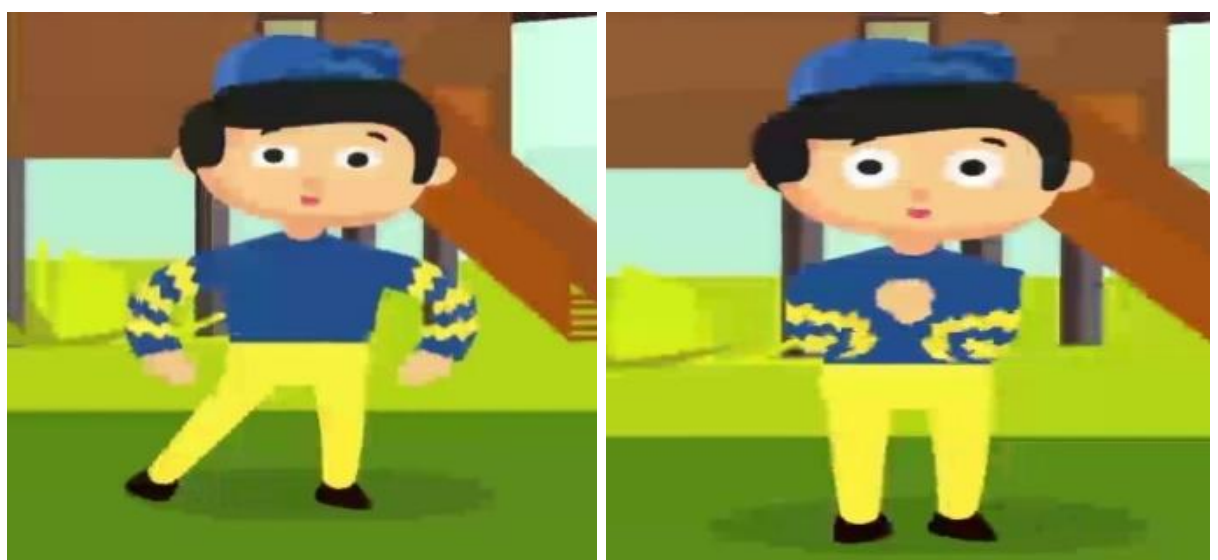

Gambar 1. Gerakan yang bermanfaat untuk kelenturan, keseimbangan dan kelincahan

\section{Gerakan ke-2}

Dua step gerakan tungkai di ikuti oleh ayunan lengan dari kanan ke kiri. Gerakan ini hampir sama dengan gerakan pertama namun gerakan ini melakukan dua langkah setiap kekanan/kekiri manfaatnya untuk melatih koordinasi kaki dan tangan yg harus disamakan dan saat mengayunkan lengan dan kaki dapat melatih kekuatan otot-otot lengan dan kaki anak, daya tahan otot lengan.

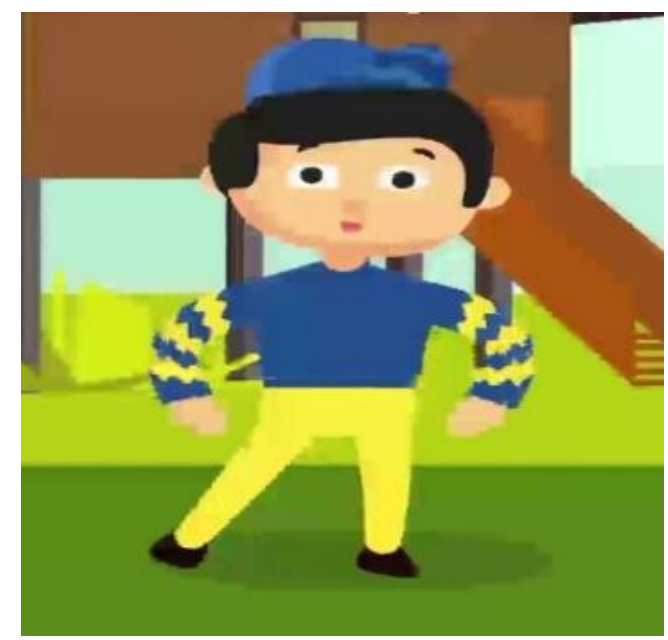

Gambar 2. Gerakan yang bermanfaat untuk melatih kekuatan otot-otot lengan dan kaki anak, daya tahan otot lengan 


\section{Gerakan ke-3}

Dua step kanan dan dua step kiri gerakan kombinasi lengan menutup dan membuka. Manfaat dari gerakan ini adalah untuk melatih koordinasi salah satu tangan dengan kaki, yang bisa membuat anak lebih terampil dalam menggunakan tangan dan kakinya.
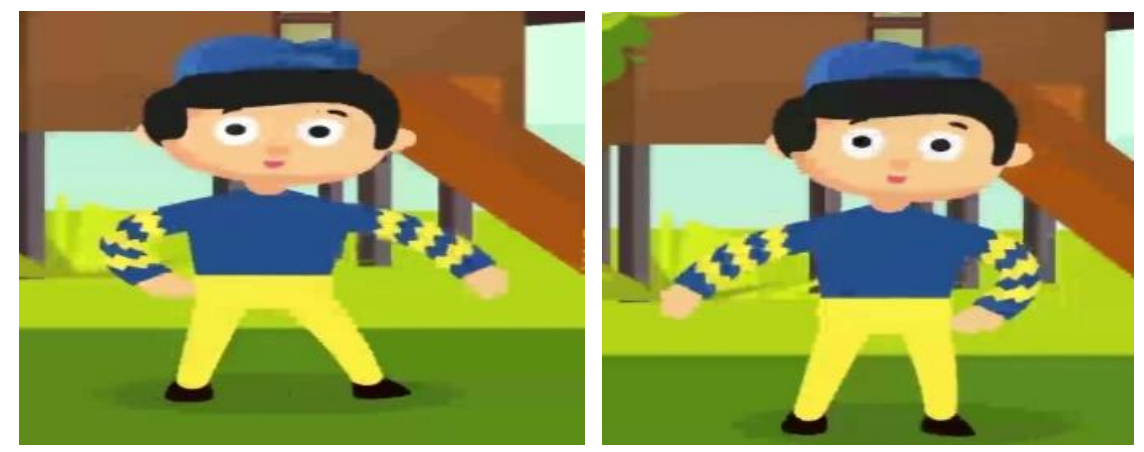

Gambar 3. Gerakan yang bermanfaat agar anak lebih terampil dalam menggunakan tangan dan kakinya

\section{Gerakan ke-4}

Dua step kanan dan dua step kiri gerakan "s". Manfaat dari gerakan ini adalah untuk melatih agar anak bisa meniru gerakan sehingga otak mulai terjadi rangsangan untuk berpikir yang bisa membuat anak cerdas.
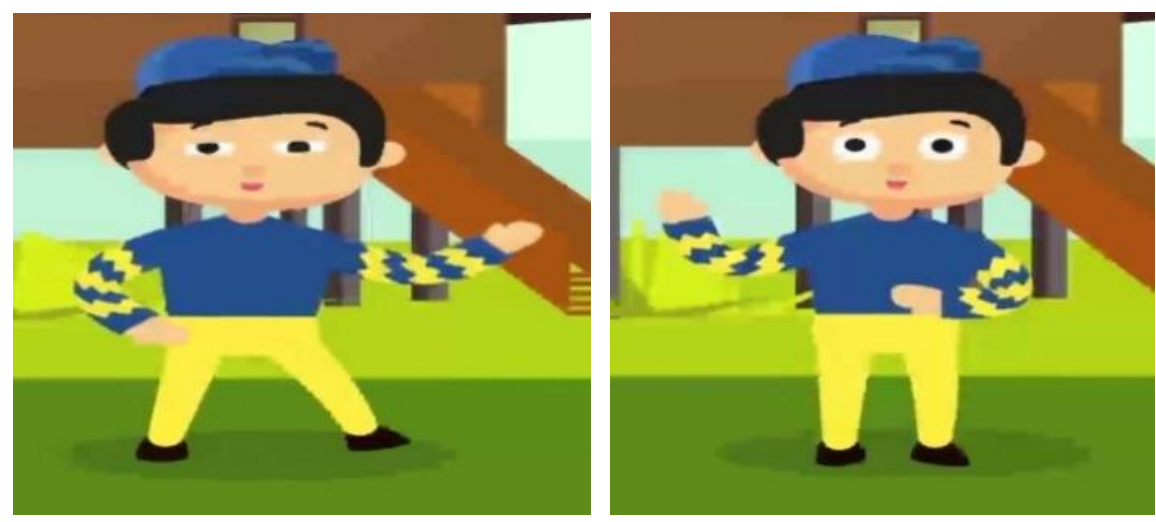

Gambar 4. Gerakan yang merangsang kemampuan berpikir anak

\section{Gerakan ke-5}

Gerakan 2 step pinggul memutar 90 derajat ke kiri dan ke kanan diikuti dengan lengan membuka dari dalam ke luar. Manfaat dari gerakan ini adalah melatih gerak pinggul sehingga anak tidak kaku, melancarkan peredaran darah dan membuat otot-otot yang awalnya kaku menjadi tidak kaku.
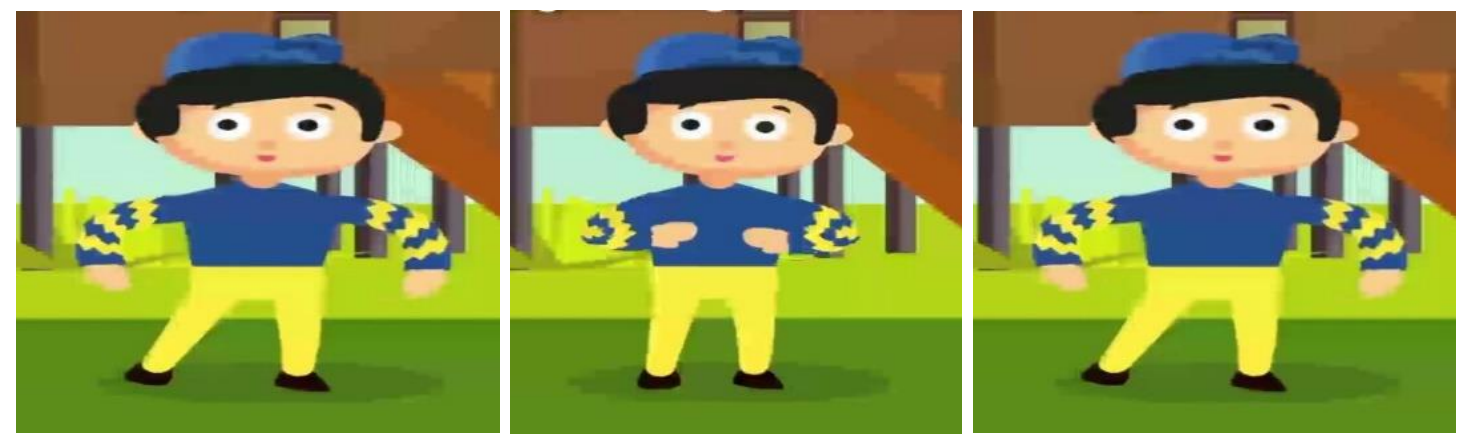

Gambar 5. Gerakan yang bermanfaat untuk melancarkan peredaran darah dan membuat otototot tidak kaku 

DOI: $10.31004 /$ obsesi.v4i1.331

\section{Gerakan senam yang diiringi lagu Cik-Cik Periok:}

\section{Gerakan pertama}

Jalan di tempat berhubungan dengan peningkatan kekuatan kaki, keseimbangan, dan koordinasi bagian-bagian tubuh yang mendukung mekanisme keseimbangan. Untuk menjaga keseimbangan pada saat memindahkan titik berat badan ke kaki depan yang melangkah, koordinasi antara kaki dengan anggota tubuh bagian atas terutama tangan sangat diperlukan.

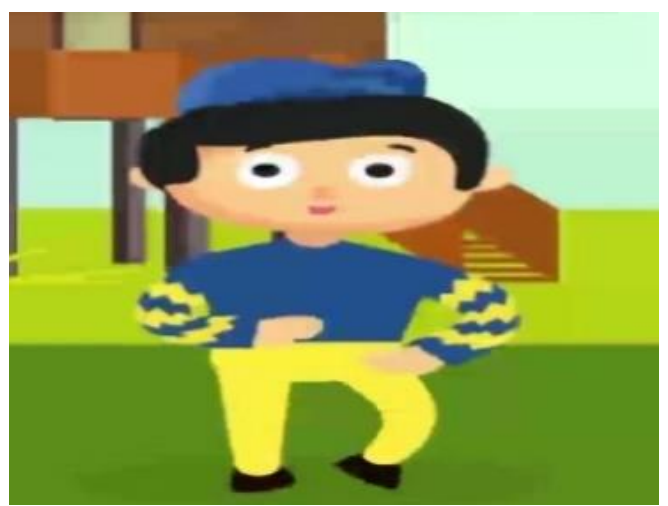

Gambar 6. Gerakan yang bermanfaat untuk menjaga keseimbangan tubuh

\section{Gerakan ke-2}

Lengan di ayun kearah depan di fokuskan pada titik otot meta karpal sambil kedua kaki di tekuk sedikit. Manfaat dari gerakan ini yaitu untuk melatih kekuatan otot, keterampilan gerak tangan dan melemaskan otot-otot yang di tangan sehingga tidak kaku, dan pada saat melakukan tekukan melatih kemampuan kelenturan lutut.
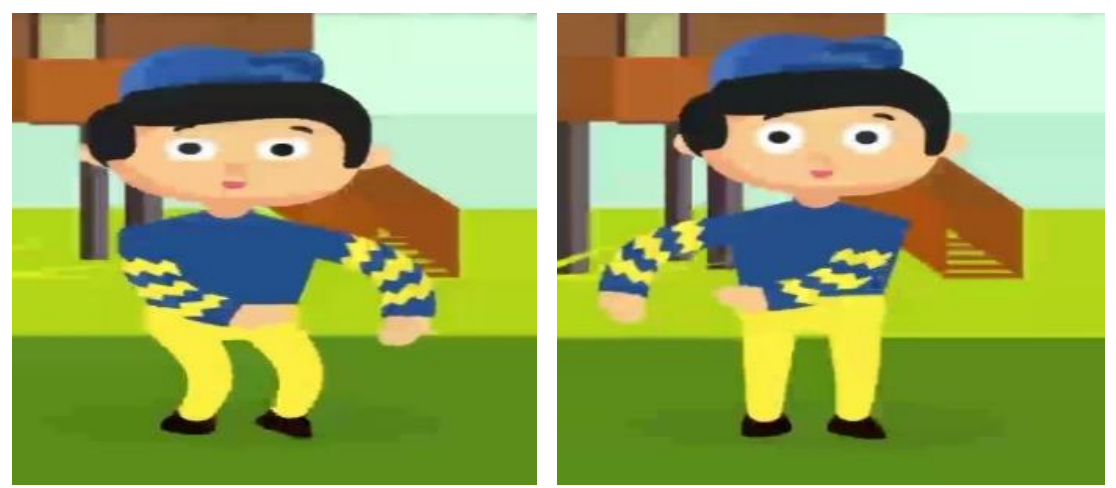

Gambar 7. Gerakan yang bermanfaat untuk melemaskan otot-otot

\section{Gerakan ke-3}

Gerakan meroda di fokuskan pada lengan dengan 90 derajat dari arah kanan ke kiri dan sebaliknya di ikuti oleh tungkai. Manfaat gerakan ini adalah melatih otot-otot yang ada pada lengan dan bahu juga melatih daya tahan otot kaki.
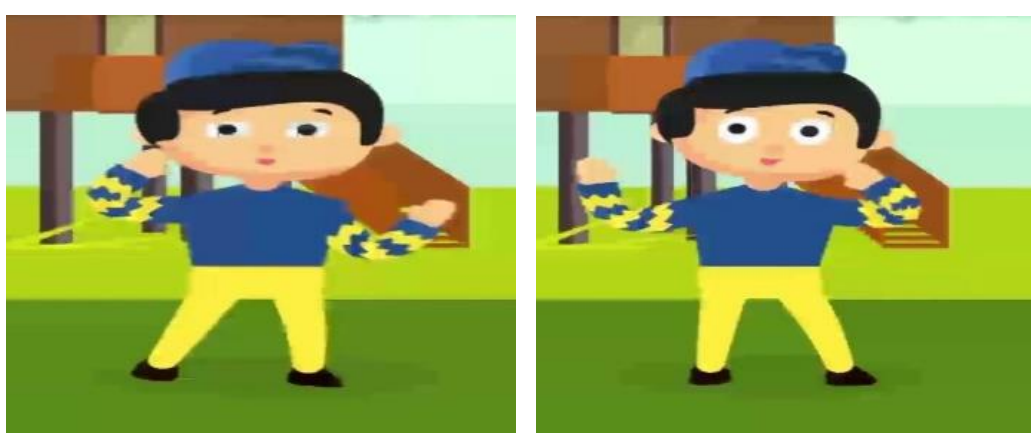

Gambar 8. Gerakan yang bermanfaat untuk melatih daya tahan otot 


\section{Gerakan ke-4}

Lengan di ayun kearah depan di fokuskan pada titik otot meta karpal. Manfaat dari gerakan ini yaitu untuk melatih kekuatan otot, keterampilan gerak tangan dan melemaskan otot-otot yang di tangan sehingga tidak kaku, dan pada saat melakukan tekukan melatih kemampuan kelenturan lutut.
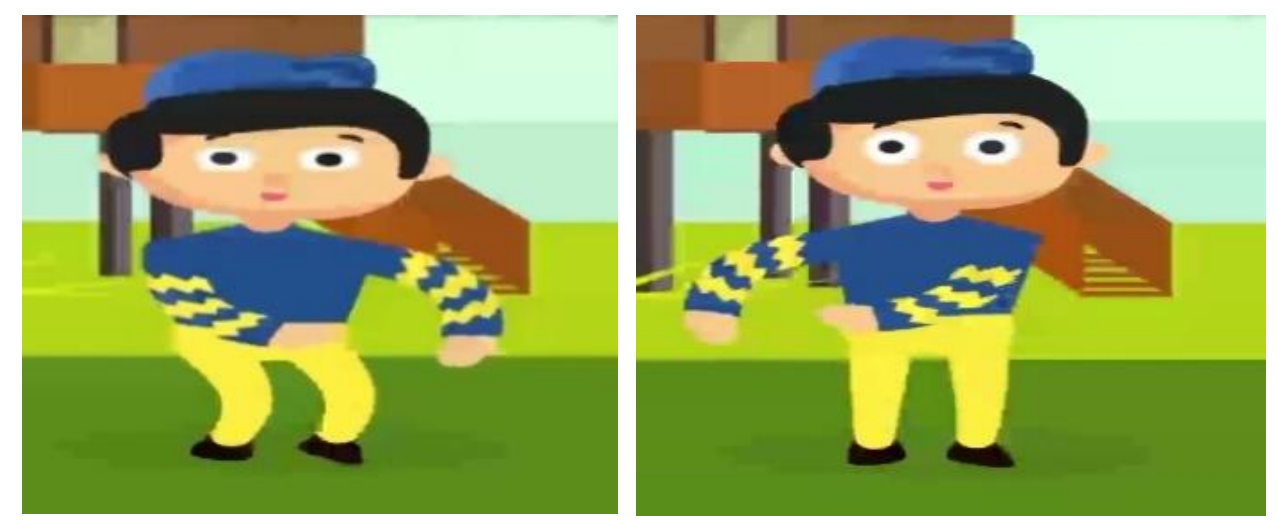

Gambar 9. Gerakan yang bermanfaat untuk melatih kelenturan lutut

\section{Gerakan ke-5}

Gerakan meroda di fokuskan pada lengan dengan 90 derajat dari arah kanan ke kiri dan sebaliknya di ikuti oleh tungkai. Manfaat gerakan ini adalah melatih otot-otot yang ada pada lengan dan bahu juga melatih daya tahan otot kaki.
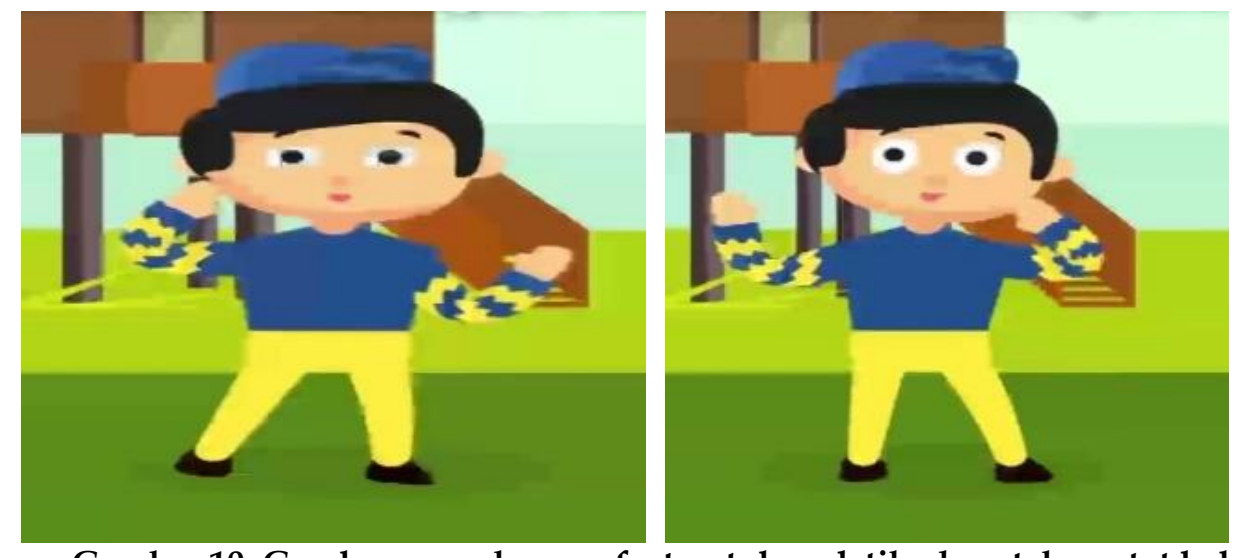

Gambar 10. Gerakan yang bermanfaat untuk melatih daya tahan otot kaki

\section{Gerakan senam yang diiringi lagu Kota Pontianak: \\ Gerakan ke-1}

Gerakan ke samping dengan 1 step tungkai dan 1 step tangan mengayunkan dari arah depan ke belakang dari gerakan menutup lengan dan membuka lengan/down swif dan up swif. Gerakan ini menggunakan tangan dan kaki secara bersamaan atau secara terkoordinasi. Manfaat dari gerakan ini adalah untuk melatih kelenturan, keseimbangan dan kelincahan.
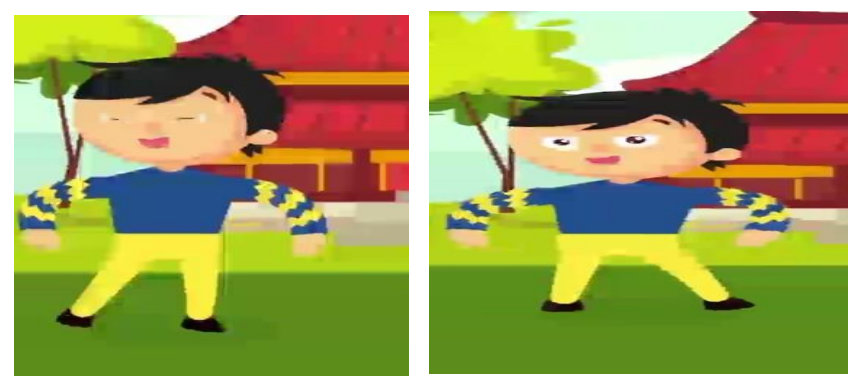

Gambar 11. Gerakan yang bermanfaat untuk melatih kelenturan, keseimbangan dan kelincahan 

DOI: $10.31004 /$ obsesi.v4i1.331

\section{Gerakan ke-2}

Gerakan pesawat 180 derajat dari arah kanan ke kiri sebaliknya merotasi dari rangkaian seluruh gerakan. Manfaat gerakan ini adalah dapat menjaga keseimbangan tubuh anak saat melakukan perputaran dan membantu melatih otot lengan.
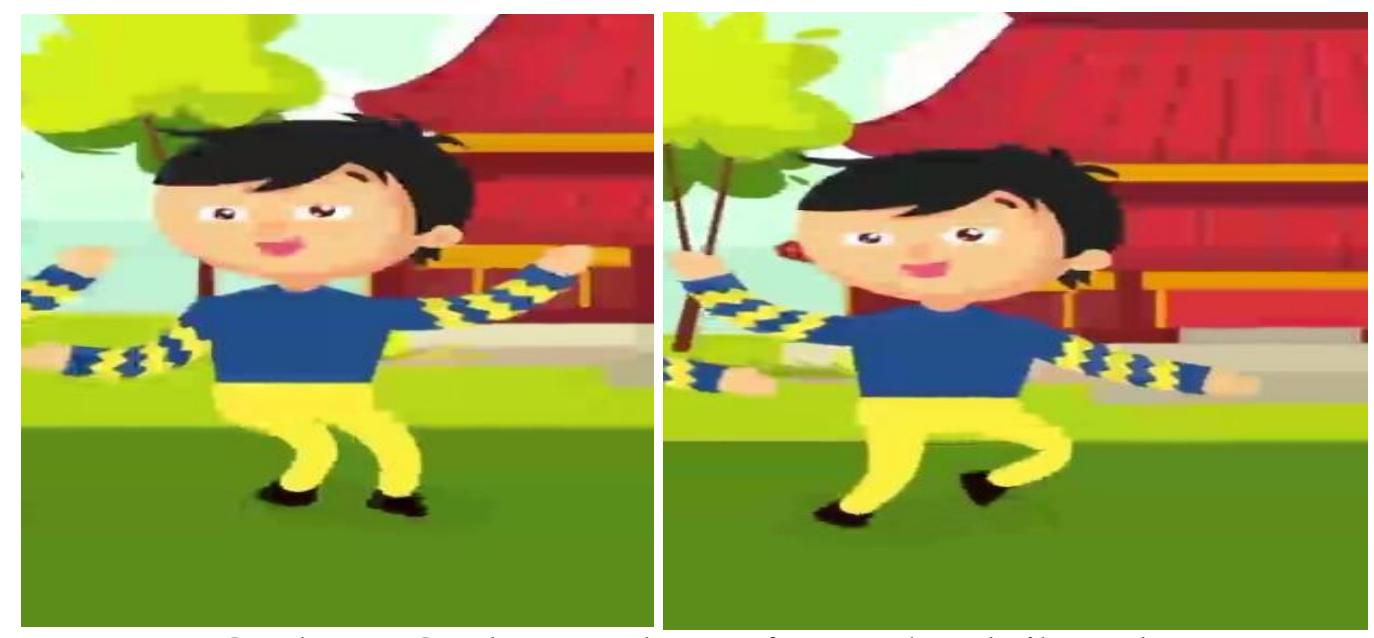

Gambar 12. Gerakan yang bermanfaat untuk melatih otot lengan

Gerakan ke-3

Lengan di ayun kearah depan di fokuskan pada titik mata karpal sambil kedua kaki di tekuk sedikit. Manfaat dari gerakan ini yaitu untuk melatih kekuatan otot, keterampilan gerak tangan dan melemaskan otot-otot yang di tangan sehingga tidak kaku, dan pada saat melakukan tekukan melatih kemampuan kelenturan lutut.
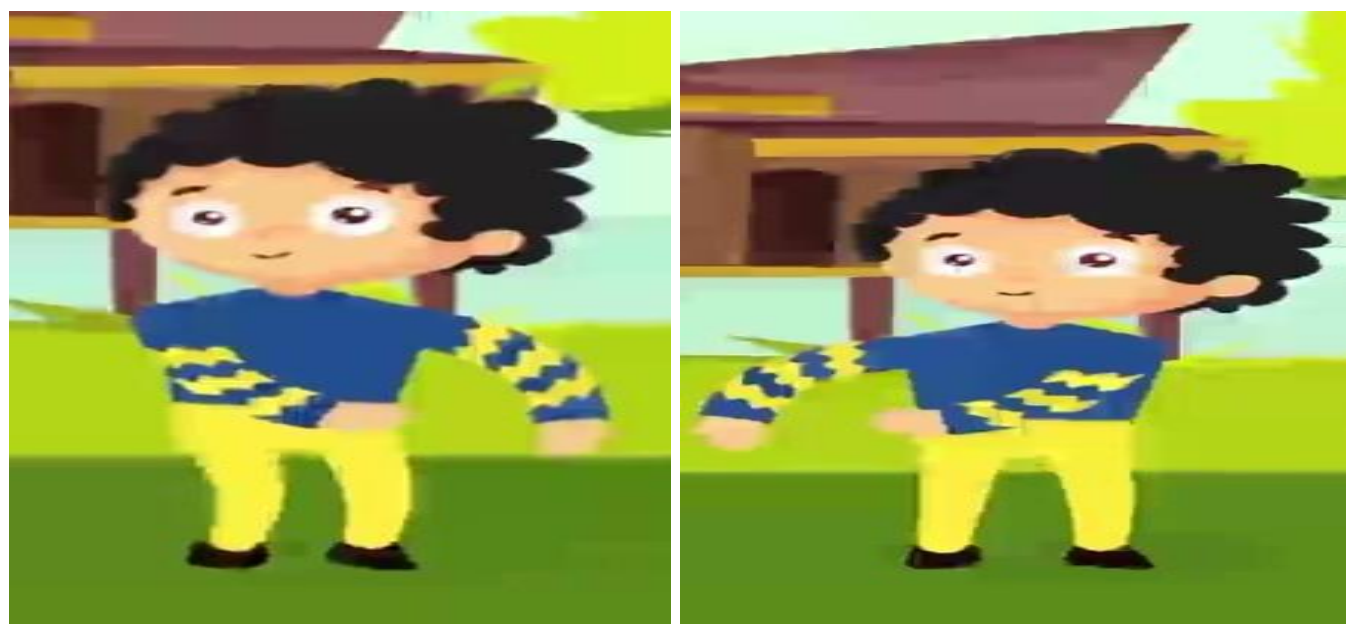

Gambar 13. Gerakan yang bermanfaat untuk melatih otot tangan

\section{Gerakan ke-4}

Gerakan melangkah kedepan dan mundur ke belakang diikuti dengan kombinasi lengan dengan posisi memendekkan dan memanjangkan lengan otot bagian dalam. Manfaat gerakan ini adalah melatih koordinasi dan daya tahan otot yg digunakan dan gerakan maju mundur termasuk dalam keterampilan motorik kasar dimana fungsi motorik kasar salah satunya yaitu sebagai alat untuk mendorong pertumbuhan dan perkembangan jasmani, rohani, dan kesehatan untuk anak. 


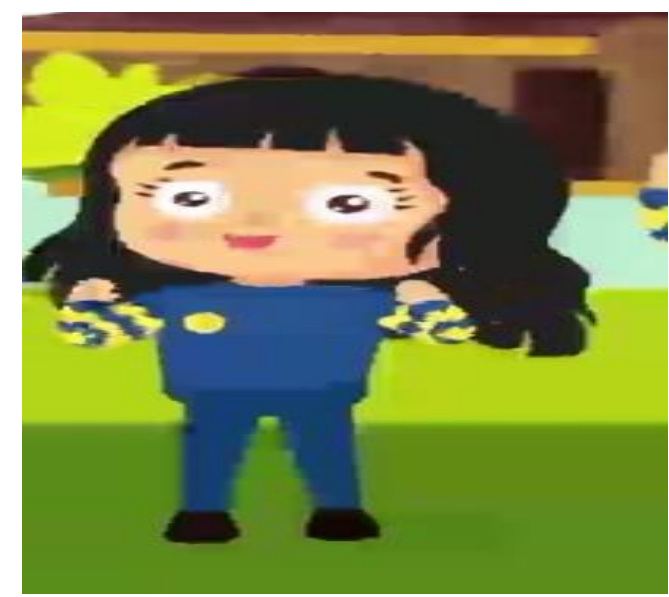

Gambar 14. Gerakan yang bermanfaat untuk mendorong pertumbuhan dan perkembangan jasmani, rohani, dan kesehatan untuk anak.

\section{Gerakan ke-5}

Gerakan ke samping kiri dan kanan dengan 1 step tungkai dan 1 step lengan mengayunkan dari arah depan ke belakang dari gerakan menutup lengan dan membuka lengan/down swif dan up swif. Gerakan ini menggunakan tangan dan kaki secara bersamaan atau secara terkoordinasi Manfaat dari gerakan ini adalah untuk melatih kelenturan, keseimbangan dan kelincahan.
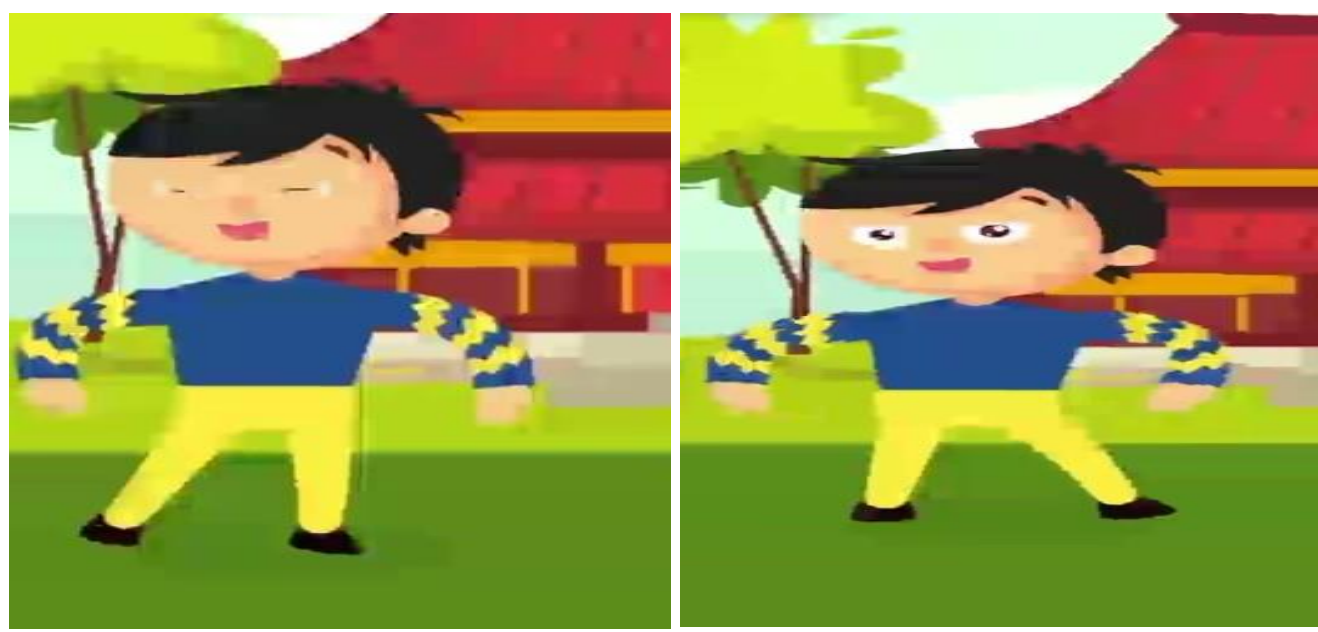

Gambar 15. Gerakan yang bermanfaat untuk melatih kelenturan, keseimbangan dan kelincahan

Selanjutnya menentukan jenis media pembelajaran. Media yang digunakan dalam penelitian ini adalam multimedia interaktif berbentuk video senam animasi 2 dimensi dengan motion graphic berbasis budaya khas Kalimantan Barat. Suyanto (2003) menjelaskan multimedia adalah pemanfaatan komputer untuk membuat dan menggabungkan teks, grafik, audio, gambar bergerak (video dan animasi) dengan menggabungkan link dan tool yang memungkinkan pemakai melakukan navigasi, berinteraksi, berkreasi, dan berkomunikasi.

Oleh karena multimedia pembelajaran yang dikembangkan dalam penelitian ini adalah multimedia dengan menggunakan perangkat komputer yang didalamnya terdapat teks berupa tulisan yang menggambarkan gerakan senam, audio berupa iringan lagu senam yang merupakan lagu khas Kalimantan Barat yang berjudul Sungai Kapuas, Cik-cik Periok dan Kota Pontianak, sedangkan gambar bergerak (video dan animasi) adalah gambar seorang anak laki-laki yang menggunakan topi dan pakaian senam bercorak insang (corak baju khas Kalimantan Barat) yang bergerak melakukan gerakan senam. 
DOI: 10.31004/obsesi.v4i1.331

Setelah ditentukan jenis medianya, dilakukan pembuatan story board. Menurut Diartono (2008) story board merupakan suatu pemetaan elemen-elemen multimedia dalam setiap layar program multimedia. Story board yang dibuat dalam penelitian ini menampilkan elemen-elemen sebagai berikut:

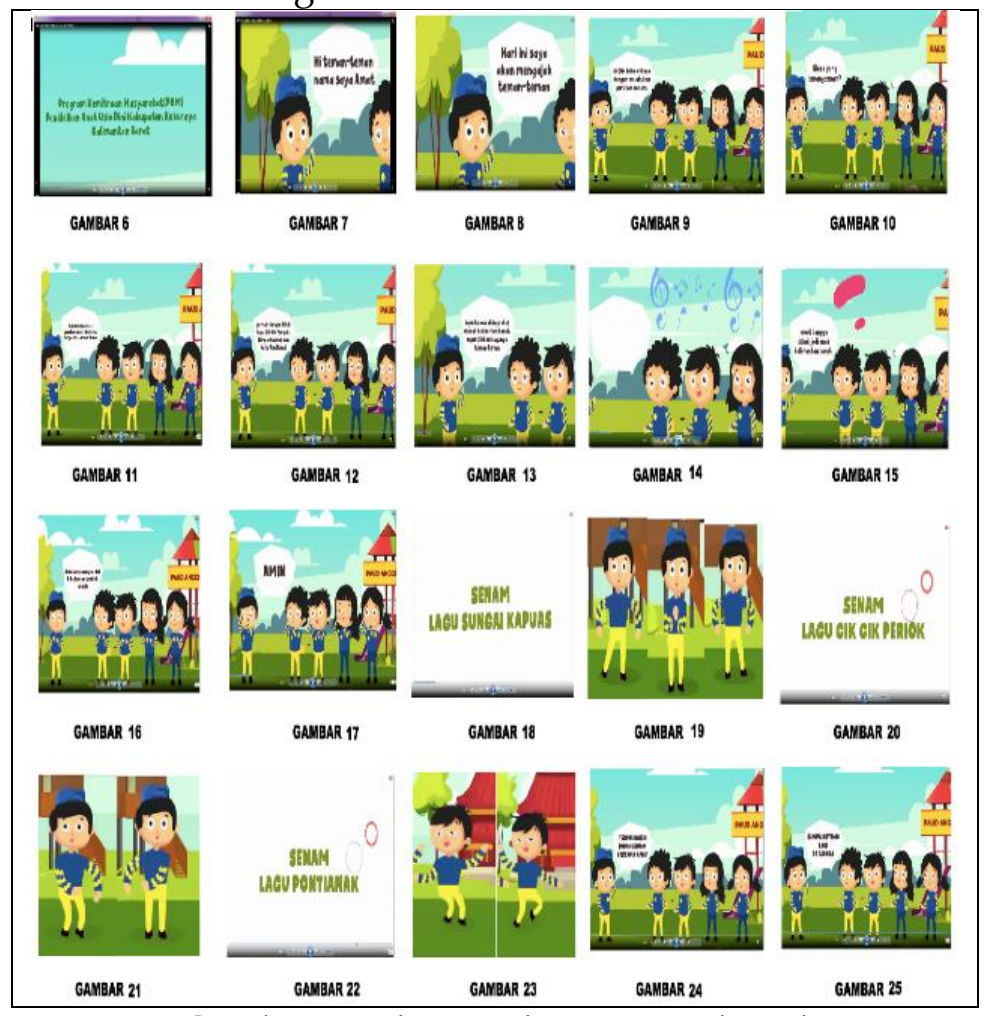

Gambar 16. Elemen-elemen story board

Story board yang dibuat dalam merancang multimedia interaktif berbentuk video senam animasi berbasis budaya khas Kalimantan Barat dalam pembelajaran di PAUD yaitu, seorang anak laki-laki berdiri di sebuah tempat yang dilatarbelakangi gambar PAUD. Kemudian ia mengucap salam dan menyapa. Dialah selanjutnya yang akan memandu aplikasi ini.

Selanjutnya terjadi dialog, "Hai teman-teman, nama saya Amat.....Hari ini saya akan mengajak teman-teman untuk berolahraga dengan melakukan gerakan senam. Siapa yang senang senam? (berhenti sebentar....untuk memberikan kesempatan audience menjawab pertanyaan tersebut. Amat senang sekali senam.....dengan melakukan senam, badan kita akan menjadi sehat, segar dan kita dapat belajar dengan perasaan senang. Sebelum melakukan gerakan senam, Amat mau tanya neh....teman-teman pernah dengar tidak lagu Cik-cik Periok......lagu itu adalah lagu khas daerah kalimantan barat. seperti ini neh lagunya teman-teman.....(ada iringan lagu dan Amat terlihat menyanyikan lagu tersebut)......bagus yah teman-teman. Selain itu juga kita punya lagu Sungai Kapuas.......Amat bangga sekali jadi anak Kalimantan Barat."

Percakapan selanjutnya, "Sebelum senam, marilah kita berdoa terlebih dahulu (Amat mengangkat tangannya selama 3 detik dan mengucapkan amin sambil mengusapkan kedua tangannya ke mukanya). Teman-teman.....yuk kita senam sambil bernyanyi dan melakukan gerakan dengan iringan lagu-lagu tadi yuuuuuuk (Amat menggerakkan tangannya seakanakan mengajak teman-temannya untuk ikut senam).

Pada tahap pengembangan, peneliti melakukan wawancara dan memberikan angket kepada 3 orang yaitu, guru di PAUD Anggrek yang berjumlah 1 orang (validator 1), dosen PG-PAUD FKIP UNTAN yang berjumlah 1 orang (validator 2) dan 1 orang Psikolog Perkembangan Anak (validator 3) untuk mendapatkan data mengenai validasi ahli materi. 
Sedangkan data validasi dari ahli media diperoleh dari 2 orang dosen di PG-PAUD FKIP UNTAN yang ahli dalam bidang media pembelajaran di PAUD.

Tabel 3. Hasil uji validasi ahli materi

\begin{tabular}{clccc}
\hline No. & \multicolumn{1}{c}{ Indikator } & Validator 1 & Validator 2 & Validator 3 \\
\hline 1. & $\begin{array}{l}\text { Kesesuaian materi dengan karakteristk anak } \\
\text { usia dini }\end{array}$ & 4 & 4 & 3,2 \\
2. $\begin{array}{l}\text { Mengandung materi yang dapat } \\
\text { mengenalkan kekayaan budaya melalui lagu } \\
\text { khas Kalbar untuk anak usia dini }\end{array}$ & 4 & 4 & 3,8 \\
3. & 3,7 & 3,8 & 3,7 \\
& Kesesuaian materi dengan aspek \\
perkembangan anak usia dini & $\begin{array}{r}\text { Jumlah } \\
\text { Rata-rata }\end{array}$ & 11,7 & 11,8 & 10.7 \\
Rata-rata semua validator $=3,8$ & 3,9 & 3,9 & 3,6 \\
\hline
\end{tabular}

Skor maksimal $=4$, skor minimal 1

$$
\begin{aligned}
\mathrm{Mi} & =1 / 2 \times(1+4) \\
& =2,5 \\
\mathrm{Sbi} & =1 / 6 \times(4-1) \\
& =0,5
\end{aligned}
$$

Kategorisasi hasil validasi dengan 4 kriteria

\begin{tabular}{lcl}
\hline No & Rentang skor & \multicolumn{1}{c}{ Kategorisasi } \\
\hline 1 & $\mathrm{x}>3,25$ & Sangat layak \\
2 & $0<\mathrm{x} \leq 3,25$ & Layak \\
3 & $1,75<x \leq 0$ & Kurang layak \\
4 & $\mathrm{x} \leq 1,75$ & Tidak layak \\
\hline
\end{tabular}

Rata-rata hasil validasi ahli materi yang diberikan validator menggunakan data angket menunjukkan bahwa multimedia interaktif berbentuk video senam animasi berbasis budaya Khas Kalimantan Barat yang dikembangkan oleh peneliti masuk dalam kategori sangat layak yaitu dengan skor 3,8.

Masukan dari beberapa validator ahli materi mengenai materi yang terdapat di multimedia interaktif berbentuk video senam animasi berbasis budaya Khas Kalimantan Barat diperoleh dari hasil wawancara, yaitu, perlunya menyesuaikan antara gerakan senam dengan ketukan dari lagu pengiring, perlu adanya tulisan 1, 2, 3 sebelum mulai gerakan

\begin{tabular}{|c|c|c|c|}
\hline No. & Indikator & Validator 1 & Validator 2 \\
\hline 1. & Kesesuaian materi dengan karakteristk anak usia dini & 4 & 3,6 \\
\hline 2. & $\begin{array}{l}\text { Mengandung materi yang dapat mengenalkan } \\
\text { kekayaan budaya melalui lagu khas Kalbar untuk anak } \\
\text { usia dini }\end{array}$ & 4 & 3,8 \\
\hline 3. & $\begin{array}{l}\text { Kesesuaian materi dengan aspek perkembangan anak } \\
\text { usia dini }\end{array}$ & 4 & 3,7 \\
\hline & $\begin{array}{r}\text { Jumlah } \\
\text { Rata-rata }\end{array}$ & $\begin{array}{c}12 \\
4\end{array}$ & $\begin{array}{c}11,1 \\
38\end{array}$ \\
\hline
\end{tabular}
senam, agar bisa dilihat oleh anak dan memberikan jeda hening beberapa detik setelah mengajak berdoa, setelahnya baru mengucapkan "Amin".

Tabel 4. Hasil uji validasi ahli media

Skor maksimal $=4$, skor minimal 1

$$
\begin{aligned}
\mathrm{Mi} & =1 / 2 \times(1+4) \\
& =2,5 \\
\mathrm{Sbi} & =1 / 6 \times(4-1) \\
& =0,5
\end{aligned}
$$


Kategorisasi hasil validasi dengan 4 kriteria

\begin{tabular}{|l|c|l|}
\hline No & Rentang skor & \multicolumn{1}{|c|}{ Kategorisasi } \\
\hline 1 & $\mathrm{x}>3,25$ & Sangat layak \\
\hline 2 & $0<\mathrm{x} \leq 3,25$ & Layak \\
\hline 3 & $1,75<\mathrm{x} \leq 0$ & Kurang layak \\
\hline 4 & $\mathrm{x} \leq 1,75$ & Tidak layak \\
\hline
\end{tabular}

Rata-rata hasil validasi ahli media yang diberikan validator menggunakan angket menunjukkan bahwa multimedia interaktif berbentuk video senam animasi berbasis budaya Khas Kalimantan Barat yang dikembangkan oleh peneliti masuk dalam kategori sangat layak, yaitu dengan skor 3,8.

Pada bagian validasi ahli media ini berdasarkan data hasil wawancara, kedua orang validator tidak memberikan masukan dan menyatakan bahwa multimedia interaktif berbentuk video senam animasi berbasis budaya Khas Kalimantan Barat ini dapat digunakan tanpa perlu perbaikan.

Hasil uji coba media kepada para anak PAUD usia 4-5 tahun dan usia 5-6 tahun di PAUD Anggrek yang berjumlah 40 orang anak. Tujuan dilakukan ujicoba ini adalah untuk mengetahui efektifitas multimedia interaktif berbentuk video senam animasi berbasis budaya Khas Kalimantan Barat.

Hasil dari uji coba tersebut adalah sebagai berikut, 100\% anak menunjukkan perhatiannya terhadap senam yang diberikan dengan langsung mempraktekkan gerakan senam seperti yang dicontohkan di multimedia, 95\% anak menunjukkan antusias dalam melakukan senam terlihat dari kelincahan mereka bersenam dan permintaan mereka untuk mengulang kembali senam tersebut ketika selesai diberikan, 90\% anak menunjukkan adanya kemampuan untuk mencontoh gerakan senam yang ditampilkan dalam multimedia saat ditayangkan serta 85\% anak dapat mengikuti gerakan senam dengan iringan lagu khas Kalimantan Barat seperti yang ditayangkan multimedia, dan $80 \%$ anak dapat menyebutkan 4 bagian anggota tubuh yang tidak boleh disentuh oleh orang lain.

Dari hasil ujicoba media tersebut, dapat disimpulkan bahwa multimedia interaktif berbentuk video senam animasi berbasis budaya Khas Kalimantan Barat yang dikembangkan oleh peneliti efektif dalam meningkat minat senam anak di PAUD.

Pada tahap penyebaran, setelah mendapat masukan dari para validator media maupun materi, multimedia interaktif tersebut diperbaiki, diberikan kepada guru di PAUD Anggrek, di upload ke youtube dan mendapatkan lisensi hak cipta.

\section{SIMPULAN}

Perancangan multimedia interaktif berbentuk video senam animasi berbasis budaya khas Kalimantan Barat, dinilai sangat layak untuk digunakan dan dapat menarik minat anak untuk melakukan gerakan senam.

\section{UCAPAN TERIMAKASIH}

Ucapan terima kasih kami sampaikan kepada pengelola PAUD Anggrek yang telah memberikan kesempatan kepada kami untuk melakukan penelitian ini di PAUD nya, melalui keikutsertaan para gurunya sebagai validator ahli materi dan juga kepada para anak didiknya, dalam melakukan uji coba pengembangan media yang telah kami rancang dan kembangkan sebelumnya.

Selanjutnya kami ucapkan terima kasih kepada DRPM Ristekdikti yang telah membiayai pelaksanaan kegiatan Program Kemitraan Masyarakat (PKM) tahun 2019 yang kami lakukan, sehingga dapat menghasilkan luaran PKM yang salah satunya berbentuk multimedia interaktif ini. Dan juga kami ucapkan terima kasih kepada semua pihak yang telah membantu dalam terlaksananya penelitian pengembangan ini yang tidak dapat kami sebutkan satu-persatu. 


\section{DAFTAR PUSTAKA}

Apta, M. (2014). Konstruksi Tes Ketrampilan Bola Basket untuk Siswa Sekolah Dasar. Jurnal Olahraga Pendidikan, 1, 32-46.

Azwar,Saifuddin. (2016). Metode Penelitian. Yogyakarta: Pustaka Pelajar.

Diartono. (2008). Modul Pembelajaran Desain Grafis Menggunakan Photoshop Berbasis Multimedia. Universitas Stikubank Semarang. Tesis Tidak Diterbitkan.

Galih Dwi Pradipta, Pamuji Sakoco. (2013). Model Senam Si Buyung Untuk Pembelajaran Motorik Kasar Pada Siswa Taman Kanak-Kanak. Jurnal Keolahragaan. Volume 1 Nomor 2. https:// doi.org/10.21831/jk.v1i2.2569.

Husdarta. (2009). Manajemen Pendidikan Jasmani. Bandung: Afabeta.

Ibda, Fatimah. (2015). Perkembangan Kognitif: Teori Jean Piaget.Retrieved Januari-Juni 2015, from Jurnal UIN Ar-raniry: https://jurnal.ar-raniry.ac.id/index.php/intel/article/

download/197/178.

Nisnayeni. (2012). Peningkatan Perkembangan Motorik Kasar Anak Melalui Senam Irama Di Taman Kanak - Kanak Bina Ummat Pesisir Selatan. Jurnal Ilmiah Pesona PAUD. Vol 1, No. 1

Paiman. (2009). Olahraga dan Kebugaran Jasmani (Physical Fitness). Cakrawala Pendidikan, $3,270-281$.

Samsudin. (2008). Pembelajaran Motorik di Taman Kanak-Kanak. Prenada Media Grup: Jakarta

Sugiyono, (2012). Metode Penelitian Pendidikan Pendekatan Kuantitatif, Kualitatif, dan R \& D. Bandung: Alfabeta.

Sujiono, Bambang. (2011). Metode Pengembangan Fisik. Jakarta: Universitas Terbuka.

Sujiono. B. 2010. Metode Pengembangan Keterampilan Motorik Anak Usia Dini. Depdikas: Jakarta

Sumantri. (2005). Model Pengembangan Keterampilan Motorik Anak Usia Dini. Jakarta: Depdiknas.

Suyanto, M. (2003). Multimedia Alat untuk Meningkatkan Keunggulan Bersaing, Andi Offset: Yogyakarta.

Vaughan, Tay. (2004). Multimedia : Making It Work. Edisi ke-6. Tim Penerjemah ANDI. Yogyakarta: Tim Penerbit ANDI.

Yuliansih. (2015). Pengaruh Senam Irama Terhadap Kemampuan Motorik Anak Usia 5 Tahun. http://eprints.ums.ac.id/37663/1/NASKAH \%20PUSBLIKASI.pdf . Diakses pada pada 26 Maret 2018

Zulkifli. (2002). Model Pengembangan Motorik Anak Prasekolah. Jakarta: Ditjen Olahraga Depdiknas. 